\title{
A VITAL PEOPLE: A NECESSITY FOR A GOOD ECONOMY
}

\author{
PHELPS, Edmund E.
}

Economics at its core is about human life in human economies. The difficulty is that economies have continued to evolve and economics has lagged behind. Modern life invaded societies in the $19^{\text {th }}$ century: first in Britain and America, later in Germany and France. Increasing numbers were driven not just by a work ethic or a desire to accumulate: They were dreamers, tinkerers, and adventurers on a journey, exercising their imagination, creativity, and curiosity. This indigenous innovation, coming from the grassroots up, was the foundation of modern life which brought people satisfactions that went beyond material rewards. It is time economics has caught up to restore the dynamism and vitality necessary for people to enjoy not only a Good Life but also a Good Economy.

Keywords: productivity growth, indigenous innovation, nonpecuniary rewards of work, social values

JEL classification indices: A13, O31, D24, J39

Phelps, Edmund E., the 2006 Nobel laureate in economics, Director of the Center on Capitalism and Society at Columbia University. Author of the books Rewarding Work (2007) and Mass Flourishing (2013). E-mail: esp2@columbia.edu 
My subject for this Special Issue of Acta Oeconomica, which commemorates the work of Grzegorz W. Kolodko for his $70^{\text {th }}$ birthday, is what Western countries must do to develop on a wide scale the prospering and flourishing which are at the heart of the Good Life and thus central to the Good Economy.

In the West, nations have been suffering for a long time from a familiar set of symptoms: meager rates of return to investment, national wage levels and national income both growing at a snail's pace, reduced job satisfaction especially among the young, high wealth-wage ratios weakening incentives to work and save, pathological public debt levels in most countries, and (in some countries) a considerable rise in working-age people unwilling or unable to participate in the labor force. Some writers speak of "the end of capitalism" (Streeck 2016).

What are the causes? Some economists, notably my friend Lawrence Summers, speak of "secular stagnation," echoing the term coined by the Keynesian Alvin Hansen in the Great Depression to suggest that "effective demand" is depressive; and another economist, Ben Bernanke, speaks of a "global saving glut," thus a deficiency of "effective demand," as Keynes called it. But, although "demand" has not been really strong over the long "stagnation," it has not been weak enough to produce the telltale signs of deflation or disinflation.

In my view, the immediate cause of the stagnation is the continuing slowdown of productivity growth - of both capital and labor - that began in America around 1968 and spread to Italy and France around 1998, and to Britain and Germany around 2004. Such a structural shift is very powerful.

The slowing of productivity growth in a country can cause all of those symptoms mentioned. The boom underway in America and Europe can be expected to boost productivity levels on the upswing, though it may well erase such cyclical gains on the way down. However, booms are not an augury of faster long-term growth.

The underlying cause of the productivity slowdowns in these economies, broadly speaking, is the net losses of aggregate indigenous innovation - losses net of gains brought by the digital revolution and other sources. The net losses were most severe in the US, UK and France. These losses alone were enough to slow the growth of productivity throughout the Western economies. It is striking that Germany lost most of its impressive indigenous innovation (President Roosevelt at one time worried that Germany would overtake America) in the late 1930s, and it has still not got much of it back, though it has found success as a "trading nation." It is also striking that Italy, which had a high rate of "imported" innovation during the catch-up years of the "50s and '60s, had only began building up significant "indigenous” innovation around 1980; then it lost nearly all of that innovation by 1995 or so. These findings 
derive from estimates by a research team at the Center on Capitalism and Society. ${ }^{1}$ I have also benefitted from the work on Italy by Gianni Toniolo and collaborators. ${ }^{2}$

The concern that many of us attach to these findings may seem puzzling to some. After all, levels of average wage rates and productivity - labor productivity, capital productivity and so-called total factor productivity - especially among older people, are still pretty high in Italy, thanks to Italy's achievement at importing new methods and products conceived and pioneered abroad. But most of us would not be satisfied with an economy in a stationary state. Many people in the West would find it disquieting to be told that innovation in the West will be limited to whatever will be achieved by the monopolists of Silicon Valley.

So what is the significance of these net losses of innovation? In the view of some economists, such as my friend Joseph Stiglitz, the main significance of the losses of innovation - in Italy, France, Britain and America - is mainly that participants in the labor force have felt deprived by the slowdown in the growth of wages. But how many centuries of wage growth does a country need to have until people have enough? Frank Ramsey and John Maynard Keynes thought in 1928 that people would be satiated with consumption and leisure within several decades. The clamor for wage growth is beginning to ring false, at least to my ears.

The main significance of what we are witnessing, as I see it, is that the losses of innovation, especially the indigenous kind, have deprived many participants of individualistic rewards, which go much deeper than "collective" rewards like earning the general wage rate and buying at the general price level or enjoying the security of a fiefdom. Let me explain.

To begin, we humans are not machines. What is most precious to us is our sense of agency and the scope of the agency we can exercise. This was what the $19^{\text {th }}$ century was all about. A new way of life was spreading: going one's own way, taking one's chances, seizing one's opportunities. Novelist Charles Dickens depicted and historian Emma Griffin documented the emergence of a new society in which people increasingly took control of their lives - many of them having careers they could not have foreseen. ${ }^{3}$ (Dickens himself led an enterprising, audacious life.) The historian Paul Johnson, documenting the beginning of

1 The estimation procedure underpinning this sketch was developed and carried out by Raicho Bojilov, a member of the research team.

See Chapter 14 of Gianni Toniolo (ed.) (2013).

She finds evidence of the new attitudes in her recent book. Her more recent focus on $19^{\text {th }}$ century materials can be expected to be even more revealing. One worker, after being promoted to the position of riveter, exclaimed how gratifying it was to be able to use his "creativity" (Griffin 1913). 
this phenomenon, dubbed it the "birth of the modern" - modern life in a modern economy (Johnson 1991).

Modernistic satisfactions are individualistic, not "collective." I see three kinds of rewards of that sort. First, one may take satisfaction in achieving something through one's own efforts and may find satisfaction from the better terms or greater recognition that might result.

These rewards are experiential and may have a creative aspect. They are about "succeeding," or, to use a narrower term, prospering (from the Latin pro spere, meaning 'as hoped, according to expectation'). Successes come in many forms: an office worker winning a raise in recognition of her unusual achievement in her job, a craftsman seeing his hard-earned mastery result in a better product, a merchant's satisfaction at seeing "his ship come in," or a scholar's sense of validation from being awarded an honorary degree.

Second, a person may find satisfaction from the unfolding of his/her life in rewarding ways: the thrill of voyaging into the unknown, the excitement of the challenges, the gratification of overcoming obstacles and the fascination with the uncertainties. ${ }^{4}$ Emerson wrote that "life is a journey, not a destination."

Last, but not least, there is the satisfaction of "acting on the world" (in Hegel's term) and, with luck, "making a mark," perhaps changing the world "making a dent," as the Beatles put it. It seems to me that these last two kinds of satisfactions are what is meant by the term flourishing.

Is there any evidence to support my claim that a large loss of indigenous innovation in a country causes employed people to experience a serious loss of human satisfaction? My book Mass Flourishing (2013: 196, 197) points to evidence drawn from the World Values Surveys. It shows, in 1990-1991 the mean level of reported job satisfaction was very low in the countries suffering low levels of indigenous innovation - Italy and France, for example - and relatively high in countries with relatively high indigenous innovation - notably Switzerland, Denmark and America. Now the same research team has extracted evidence from 2008 data in the European Values Surveys. ${ }^{5}$ It shows that, among 13 economically advanced western European countries, those ranking lowest in reporting "high" or "somewhat high" job satisfaction - Spain, France and Italy - ranked very low in indigenous innovation as well

4 Though our discussions of values differ, Kolodko and I agree on the satisfactions to be gained from overcoming difficulties and facing challenges. For his discussion of values, see his chapter "Economy without Values is Like Life without Sense," in Whither the World: The Political Economy of the Future (2014b: 161-188).

5 Data in the European Values Surveys are usually found in World Values Surveys, but not in cases where American data to accompany them are not available. 
$\left(9^{\text {th }}, 11^{\text {th }}\right.$ and $13^{\text {th }}$ place, respectively) and those ranking highest in job satisfaction - Switzerland and Denmark - ranked very high in indigenous innovation (in $2^{\text {nd }}$ place and $4^{\text {th }}$ place, respectively).

What was the source - the wellspring - of the indigenous innovation that, in several countries, brought the satisfactions I call prospering and flourishing? And what has been causing the losses of this innovation? I have maintained for years that the source was the rise of the modernism that sprung up in southern Europe in Renaissance times. One could argue that the modernist influence began with the great scholar Pico della Mirandola. ${ }^{6}$ He openly argued that mankind possesses creativity. The voice of some other figures stirred people to use their creativity - the ambition of Cellini, the individualism of Luther, the vitalism of Cervantes and the personal growth of Montaigne and, later, the need for imagination in Hume and the acceptance of the unknown in Kierkegaard. Some $19^{\text {th }}$ century philosophers, such as Charles Peirce, William James, Friedrich Nietzsche and Henri Bergson embraced uncertainty and relished the new.

In my book I also maintain that innovation was also pervasive - in all or most industries - and inclusive - from the grassroots of society on up. Much, perhaps most, of the contribution of innovation to economic growth can be laid to the new ideas of ordinary people engaged in ordinary business life. The work they did every day led them to conceive of possibly better methods in farms, factories and offices - though they must have been aware that commercial success was uncertain. Pico would have understood this.

You may be wondering: Is there evidence to back the thesis that the desire to innovate is fueled by values? Yes there is, thanks to some ingenious research: A statistical analysis by the same research team of data from a cross-section of 18 countries in the OECD shows that the countries with higher economic performance (as measured by job satisfaction and labor force participation rates) tend to have higher levels of the right values or lower values of the wrong ones. ${ }^{7}$

Accordingly, I maintain - regarding the present day - that the serious deficiency of indigenous innovation in one country after another in Western Europe and North America has come not from an absence of profitable possibilities and not from any omissions of the public sector (like bridges and tunnels not built) but from a decline of the modern values that sparked the desire to innovate. ${ }^{8}$

6 I am told that at Oxford as late as the $17^{\text {th }}$ century Aristotle was known as the Philosopher, since he had appeared to have thought through so much of what was to be understood, and Pico was known as the Scholar, because he knew everything that was known in his time.

$7 \quad$ The statistical procedure behind this research employs a method created by Harold Hotelling and was carried out by Gylfi Zoega, a member of the research team.

8 This is a critical thesis of my book (2013). 
Economists missed this. They were either Schumpeterians believing that the innovations we observe were obvious applications by an experienced entrepreneur of a scientist's discovery, or they were Hayekians believing that what we really observe are merely the "adaptations" that result when unseen and evolving opportunities are intuited by an insightful businessman."

What has happened in the realm of values that may account for the weakness of indigenous innovation in Italy and Britain, in France and in America? When we think of the momentous innovations in those countries, it is almost unimaginable that modern values have been lost or opposed.

Yet, I wonder whether Americans are still do-ers. Do they love to compete as much as in the decades from, say, the 1850s up to the mid-1960? Or are they still the couch-potatoes that was once said about them? Are they fixed on all the tweets coming in by the hour? Perhaps, they have lost the motivation which Kolodko identifies (2008), and rightly so, as key for economic growth.

Are Americans and other Westerners too afraid to act? It appears to me that in the present age - since World War II - there is a dread of "Knightian" uncertainty (named after Frank Knight (1921) and Keynes (1921), who also introduced the concept). People came to be uncomfortable with the directionlessness that modernist values injected into the economy. The loss of their former fascination with voyaging into the unknown - which is an element of expressionism - is one of the causes of the serious loss of dynamism, thus a serious loss of innovation. (I did not say disappearance of innovation, only a serious loss of it.)

The flagrant short-termism of corporate heads and our representatives in legislatures - witness the tax cuts proposed in Washington - is another hypothesis. Answering a query from Larry Summers, I looked into what has happened to the steepness of the yield curve since the earliest period to recent periods. The trend has been up. In the period 1925-1932, the average 10-year rate was only 0.05 points above the average 3-month rate. In the period 1994-1996 it was 1.93, in 2003-2005 and in 2016-2017 it was 1.51 (Coleman et al. 1993). ${ }^{10}$ These observations are consistent with the hypothesis that asset managers and clients are more averse to long-term assets, with their relatively high element of uncertainty, than they were in the span of normal years in the Interwar period. However, the hypothesized rise of short-termism is not outside my framework of modernist values. It looks to me like a loss of vitalism.

I also sense there has also been a decline of individualism in the West. Where are the Horatio Alger stories? Where are the young people asking the Horace

$9 \quad$ See Joseph Schumpeter’s book (1912) and Friedrich Hayek’s widely known article (1945).

10 For later data see the "Resource Center" of the U.S. Department of the Treasury's website. 
Greeleys in what direction to go? I am shocked that young Americans report in opinion surveys that they want to remain in their home town, live close to their friends or even continue to live at home! (Tuttle 2012). This is a portrait of America that is almost unrecognizable to me. Certainly it is not the nation that Norman Rockwell painted and Willa Cather wrote about.

There are other hypotheses, most of them a reversion to the tenets of corporatism, about which I will say more a little later. There is the rise of the "money culture," as John Dewey called it. There is also the strange and perverse love affair of most Americans and Europeans (including Brits) with houses - Rome and New York are rare exceptions - which is another kind of materialism. ${ }^{11}$

There is more than a deficiency of modern values behind the decline of innovating. Society has come to subscribe to some antithetical values, which may interfere with modern values. A new set of values arose under the name of corporatism in the 1890s - in Germany, France and Italy - and put into practice in the Interwar period. The essence of this doctrine is that the society is a coordinated "body" (corpore), so companies ought not to do what would harm the state and may be obliged to act for the good of society, wich is antithetical to individualism. A would-be innovator might well be looked at as selfish and, to the extent he or she succeeds, disruptive and thus anti-social.

In recent decades, neo-corporatism sees it as an obligation of society to extend social protection to various groups and to ensure that all groups advance in lockstep. Neo-corporatism also sees it as acceptable that companies protect themselves from competition from others. Call it self-protection. This has led to an unprecedented acceptance of monopoly power. The emergence of abusive use of patents and protectionist regulations are other examples. I would only make the point that an economy needs some basic patent protection and some basic regulations, but a forest of regulation and patents makes it burdensome for individuals to start new companies and presents legal hazards to employees and managers inside existing companies who would have liked to try out new methods or policies. Why has society allowed these governmental abuses to arise? In part, my answer is that, much of the citizenry have lost their allegiance to modernist values.

Finally, politicians have taken ad hoc measures that directly block competition from new ideas. The entry of startup firms is impeded through a variety of actions - from tariffs and quotas to outright aid to incumbents - to save established companies from losing market share. Furthermore, when incumbents become

11 An extreme example of materialism is overconsumption as highlighted by Kolodko (2014a), who posits that human needs are growing faster than the degree to which the economy can satisfy them. See his essay, for a fuller discussion in which he calls for an "economics of moderation". 
safe from firms with new ideas, they can afford to cut back whatever defensive innovation they might have done. All this represents a serious rejection of individualism in favor of collective action.

So we are faced with significant alienation from the modern values - the necessary individualism, vitalism and expressionism - that drove massive innovation in the lead economies of the West. And we are faced with a rise of post-modern values that celebrate every non-profit enterprise more than any commercial one. To regain the dynamism of old we need to return to those modernist values and reject the post-modern ones.

\section{REFERENCES}

Coleman, T. S. - Fisher, L. - Ibbotson, R. G. (1993): Historical US. Treasury Yield Curves. New York: Moody Investor's Services.

Griffin, E. (2013): Liberty’s Dawn. New Haven, CT.: Yale University Press.

Hayek, F. (1945): The Use of Knowledge in Society. The American Economic Review, September. Reprinted in his essays (1948): Individualism and Economic Order. Chicago: University of Chicago Press.

Johnson, P. (1991): The Birth of the Modern World Society 1815-1830. HarperCollins Publishers.

Keynes, J. M. (1921): A Treatise on Probability. Macmillan \& Co.

Knight, F. H. (1921): Risk, Uncertainty, and Profit. Boston: Houghton Mifflin Co.

Kolodko, G. W. (2008): Truth, Errors, and Lies. Columbia University Press.

Kolodko, G. W. (2014a): The New Pragmatism, or Economics and Policy for the Future. Acta Oeconomica, 64(2):139-160.

Kolodko, G. W. (2014b): Whither the World: The Political Economy of the Future. Palgrave Macmillan.

Phelps, E. (2007): Rewarding Work. Harvard University Press.

Phelps, E. (2013): Mass Flourishing. Princeton: Princeton University Press.

Schumpeter, J. (1912): Theorie der wirtschaftlichen Entwicklung. Leipzig: Dunker \& Humblot.

Streeck, W. (2016): How Will Capitalism End. Essays of a Failing System. London - New York: Verso.

Toniolo, G. (ed.) (2013): The Italian Economy since Unification. Oxford: Oxford University Press.

Tuttle, B. (2012): Being 30 and Living with Your Parents Isn't Lame - It's Awesome. Time Magazine, March 20, 2012.

World Values Surveys. 